\title{
Meniace sa historické naratívy: „Všetko jasné!"
}

\author{
Changing historical narratives: „Everything's clear! ”
}

DOI: 10.31577/EtnoRozpra.2021.28.2.07

\section{Helena Tužinská}

\section{Abstract}

The paper addresses questions concerning change as a fundamental variable in historical narratives and resistance to it. Group identification plays an important role in the formation of narratives, which is situational, multiple, changeable, and also composed of We and Us, for contrast with others. The author discusses how the perspective of the Other can be extracted from history and geography textbooks of neighbouring countries and historical minorities. The reproduction of cognitive bias, especially (ethnic and racial) stereotypes, may represent a problem. What is crucial in this investigation is that not in every society or geopolitical space, and not in every historical time, have people defined and are defining themselves through race or ethnicity. In the past, status was more significant; today it may be an acquired identity through activities in transnational corporations or in religious and other ideologically oriented groups. The author concludes by turning her attention back to the way data is collected and interpreted, especially the "truth" in the eye of the beholder.

\section{Key words}

ethnicity, race, narratives, history, change, perspective, bias

\section{Klúčové slová}

etnicita, rasa, naratívy, história, zmena, perspektíva, zaujatost

\section{Acknowledgement}

Vydanie príspevku bolo podporené grantom VEGA č. 1/0194/20 Morálne naratívy o náboženských a etnických skupinách vo vyučovaní vybraných predmetov na základných školách.

\section{Kontakt / Contact}

doc. Mgr. Helena Tužinská, PhD., Filozofická fakulta Univerzity Komenského v Bratislave, 
Gondova 2, 81102 Bratislava, Slovenská republika, e-mail: helena.tuzinska@uniba.sk ORCID (iD https://orcid.org/0000-0003-1135-3007

\section{Ako citovat' / How to cite}

Tužinská, H. (2021). Meniace sa historické naratívy: „Všetko jasné!“. Etnologické rozpravy, 28(2), 71-78. https://doi.org/10.31577/EtnoRozpra.2021.28.2.07

\section{Forma nejestvuje.}

Forma je nehybná a realita je pohyblivá.

Skutočná je len neustála zmena formy.

Forma je momentálny záznam zmeny.

Henri Bergson

\section{Tichý dialóg verejného a lokálneho diskurzu}

V oficiálnom a verejnom diskurze, $v$ učebniciach aj v masmédiách sa na prvý pohl’ad môže zdat', že reprezentovanie dejín národnostnej menšiny je prítomné do tej miery, aké silné má aktuálne politické zastúpenie v štruktúrach, ktoré napríklad o tvorbe učebníc a kurikúl rozhodujú. Lokálny diskurz je nemenej dôležitý, prítomný v regionálnej tlači, televíziách, sociálnych sietach či na kultúrnych podujatiach obcí. Predpokladám, že dejinám menšín v lokálnom diskurze je venovaná pozornost', ak majú aj politickú zhodu s reprezentáciou obce (prenesene Cuius regio, eius religio).

Pri tomto reprezentovaní sa robí dôraz na statickost' etnickej a rasovej identifikácie, čím sa živí pôda pre šírenie stereotypov. Zabúda sa na flexibilitu skupinovej identifikácie (Eriksen, 1995), ktorá je:

1. situačná, $v$ závislosti od symbolického oprávnenia a osobných skúseností

2. premenlivá, v závislosti od meniacich sa systémových hraníc a vnímaných sociálnych kontrastov

3. zložená z "my" (pre vnútornú súdržnost) a z "nás" (videných zvonka) pre kontrast s druhými

4. viacnásobná (spolupatričnost’ s viacerými skupinami naraz sa nevylučuje).

Každý z nás pochádza z rodov s predkami rôznych príslušností, je len otázkou (ne)do72 stupnosti historických záznamov, aby sme ich paletu vedeli konkretizovat'. Eriksen (1995: 
435) tvrdí, že jednotlivci, ktorí sú členmi viacerých skupín, založených na rôznych princípoch - trieda, etnicita, rod, profesia, náboženské a politické presvedčenie a d’alšie - sú menej naklonení nekompromisne investovat’ do konfliktov než tí, ktorí celú svoju osobu definujú vo vzt’ahu k jednej skupine (napríklad rasovej alebo etnickej). Podčiarkuje tiež možnost' vykračovat’ z polaritného "My-Oni“ a tak rámcovat' etnický kontrast nekonfliktným spôsobom ako „My-Nás“ (we-hood and us-hood) v zmysle rovného nazerania na seba očami druhého.

Pravdaže si uvedomuje, že už aj slovo „my“ je situačné, pretože sa spravidla vztahuje na rôzne kolektívy v závislosti od kontextu. „My“ implikuje „oni“, inklúziu aj exklúziu (Eriksen, 2015: 2). Eriksen vysvetl'uje, ako luudia nemusia byt' kultúrne a zároveň sociálne integrovaní. Napríklad, niekto hovorí úradným jazykom a pozná zvyky, ale nemá lokálne sociálne siete alebo naopak, má sociálne siete cez prácu, ale neovláda reč a lokálne zvyky. Strach zo straty národnej identity je podl'a neho často výsledkom skúsenosti, že kultúrna integrácia sa deje bud' na privysokej úrovni - transnacionálne či globálne - (viac zahraničnej TV produkcie než vlastnej, lokálnej), alebo je „škála prinízka/priblízka, preto neschopná mobilizovat' obyvatel'ov naprieč krajinou tak, aby vytvorila abstraktnú komunitu“" (Eriksen, 2015: 19).

Spravidla si však v každodennom živote tieto nuansy l'udia nemajú prečo uvedomovat'. Pripisovanie skupinovej identifikácie môže vyvolávat $v$ jej členoch, ako aj nečlenoch rôzne pocity. Pocity voči vlastnej a iným skupinám ovplyvňujú názory a postoje, ktoré k nim máme. Emocionálna reakcia tak môže byt’ spúštačom presvedčení, stereotypov, predsudkov aj konania. Tieto procesy majú evolučný význam, nespustia sa však za každých okolností. V propagande sú zneužitel'né, ak l'udia uveria, že sú prirodzené a nemenitel'né. Hladajú premisy pôvodnosti, autochtónnosti, aboriginality, nativity, pravosti, tradicionality. Naučené rozdiely ponúkajú nálepky pre šírenie predsudkov a diskrimináciu s politickými ciel'mi (pozri napríklad Lešková, Uhrin, 2020). Človek je však tvor tvorivý, s kapacitou nielen ovládat' vlastnú pudovost', ale aj nachádzat' spoločný význam pojmu l'udskost'. Verejný a lokálny diskurz potrebujú vytvárat' komunikačné priestory na dialóg. Ak nedostanú miesto, pestrost' skupinových identifikácií bledne, hnedne, červenie...alebo nemá vôbec žiadnu farbu, a o slovo sa prihlásia biele miesta.

\section{Biele miesta: učebnice susediacich krajín, spojte sa!}

Za perspektívne línie výskumu pri vypĺńaní „bielych miest“ v dejinách danej etnickej minority považujem tie, pri ktorých sa výskumník riadi pravidlom „nemusím sympatizovat', ale môžem empatizovat" (Atran, 2010) a tak dokáže predstavit perspektívy aj tých aktérov, ktorí by danej etnickej menšine nepriali ani prežit. Ako nekorektný sa mi javí postup, ktorý obchádza komplexnost' výskumného problému, a v konečnom dôsledku stereotypizuje (a zväčša aj politizuje).

Opustit autostrádu a vybrat si cestu, ktorá vedie k detailným objavom, znamená stratit’ očakávanú rýchlost'. „Biele miesta“ nie sú len tie, ktoré nemajú historickú mapu, ale aj tie, ktoré nereflektujú navigačný systém ako taký. Pod navigáciou v súčasnom poznaní ohladom rasových a etnických klasifikácií myslím procesy ich tvorby a šírenia. Známe kognitívne skreslenie, ktoré je často využívané v propagande, je stereotyp. Tento pojem je prevzatý z tlačiarenského priemyslu - predstavuje štočok (fr. cliché), teda odliatok, ktorý 
podstatne zrýchluje tlač (Wikipedia, b. d.). Preto stereotypom označujeme zrýchlené, mechanické, teda prevzaté šírenie reprezentácií (Tomek, 2018). V tejto súvislosti výnimka odkazuje na priam nemožný proces „vyňatia“ z odliatku. Výnimka totiž s fixovaným odtlačkom „nesedí“. Že sa mysel' celého stereotypu vzdá, je menej pravdepodobné, ako to, že si ho potvrdí.

Navigačný systém mysle má svoje evolučné opodstatnenie. Napriek tomu, že pri triedení dát najprv ponúka „autostrády“, ak má k dispozícii dostatočne podrobnú mapu, potrebuje mat' i motiváciu si ju priblízit'. Kartografi a kronikári majú moc vybrat z množstva dát tie signifikantné (ak Google mapám firma nezaplatí za zobrazenie svojej adresy, ostáva jej miesto biele.) Tak si počínajú aj „historické mapy“ - ponúkajú „autostrády“. Nezanedbatel'nú úlohu v tvorbe týchto máp majú aj dôveryhodné osoby mimo školy. Aký dodatočný výklad histórie deti počúvajú od rodičov, starých rodičov alebo iných príbuzných či okolia? „Ako ste sa to učili v škole? Ja ti vysvetlím, ako to bolo naozaj!“ (počas Slovenského štátu, SNP, repatriácie, kolektivizácie, ....).

Teraz si predstavme, že by sme sa narodili na rôznych miestach Slovenska, s inou než majoritnou národnost’ou. Ako by sa nám čítali v škole s vyučovacím jazykom slovenským súčasné učebnice dejepisu, občianskej náuky alebo geografie, ak by naši rodičia boli Rómovia, Židia, Nemci, Česi, Mad’ari, Rusíni, či z inej menšiny (viac pozri Botík, 2007)? Aký komunikačný priestor je menšinám venovaný v súčasných učebniciach? Pretože správne tušíme, že skromný, Štátny pedagogický ústav (2020) vydal doplnkový učebný materiál pre ZŠ Národnostné menšiny - zoznámme sa. Každej z trinástich národnostných menšín žijúcich na území dnešného Slovenska je venovaných šest’ strán o histórii ich príchodu, súčasnosti aj tradíciách. Pokračovanie dialógu by predstavovali otázky z učebníc týchto menšín, ktoré boli písané pre ich vlastných žiakov. Samostatný priestor by si zaslúžili menšiny, ktoré majú niekol'ko desatročí názov „nové“.

Možností ako šíreniu etnických a rasových stereotypizácii predchádzat' je množstvo. Osobný kontakt, spoločné projekty, kultúrne akcie... alebo aj prehl'ad dobových učebníc (vrátane súčasnosti) viacerých etník. Žiaci tak majú možnost' pozorovat’ samotný proces tvorby historického naratívu, pýtat' sa na príčiny zmeny pera kronikára a kartografa.

Angelica Dass kombinuje fotografiu, sociológiu a ludské práva - v projekte Humanae predstavuje ludí všetkých odtieňov a prirad'uje im číslo podl'a medzinárodnej klasifikačnej stupnice Pantone (Dass, b. d.). Z pestrej palety je na prvý pohl'ad zrejmé, že pät rás tak, ako sú v siedmackej učebnici občianskej náuky, nestačí. Je tam tol'ko „výnimiek“, že nestačia ani podtypy, pretože pri akejkol'vek snahe výnimku presne definovat', objaví sa d’alši „nezaraditel'ný“. Philip Kottak uvádza, ako v brazílskom Arembepe si l'udia v dedine so 750 obyvatel'mi určili 40 rasových typov, pričom označenie jednotlivých typov nielen menia podla potreby, ale určujú ich aj podla rôznych, navzájom neporovnatel'ných kritérií (Kottak, 1983).

M. Hrabovský, autor monografie Rasa - rasové klasifikácie l'udí vysvetl'uje históriu spojenia farby pleti s menejcennostou. Toto spojenie bolo „jednou z najmocnejších a najdeštruktívnejších intelektuálnych myšlienok všetkých čias“ (Jablonski, 2012, citované podla Hrabovský, 2018: 53). Rasa dodnes nemá všeobecne prijímanú vedeckú definíciu, a teda ani stanovitel'ný počet. Mysel' však rada zoskupuje, naturalizuje, tvorí „prirodzené druhy“ a pripisuje im nezmazatel'nú esenciu. Je to jeden zo spôsobov, akým mysel' organizuje 
poznatky o prírode a spoločnosti. Neskúmame však poznatky o esencii, ale len reprezentácie esencie (Kanovský, 2004). Podlahnút tomuto klamu by bolo rovnako nerozvážne, ako trvat' na geocentrizme len preto, že je vol'ným okom pozorovatel'ný. Napriek tomu, že „nejestvujú žiadne ostré hranice, len plynulé prechody“ (Krekovič, 2015), mysel' tiež ponúka „medzirasový efekt“, teda jav, že sa nám l'udia „inej rasy“ javia rovnakí. Dočasu - až po dlhšom čase pozorovania si začneme uvedomovat aj v rámci jednej skupiny rôznost' jednotlivcov (Hugenber a kol., 2007).

Už len samotné uvedomovanie si tejto predispozície pomáha. Na definíciách záleží. Milan Hrabovský detailne ukazuje, ako „rasa“ nie je príčina identifikácie, ale dôsledok inštitucionálnych praktík a spôsobov, akými sa o nej hovorí a koná. Preto je vo výskume cestou intersekcionálna analýza, ktorou sa sledujú možné z/zne/výhodnenia ako súčin viacerých reprezentácií, vrátane tých o rode, etnicite, statuse, vierovyznaní a iných.

Zaujatost' rasou $v$ „image society“ môže súvisiet’ aj so vzhl’adom, ako dôležitým zdrojom sebadefinície. Esencializácia sa charakterizuje tak pozorovatel'ne, ako aj neviditel'ne, pričom na svoju legitimizáciu používa aj genetiku. Komerčné genetické testy z analýzy sliny (Sørensen, 2016) majú jasný antirasistický odkaz, zároveň však predstavujú farebnú mapku a percentuálny pomer „etnicít“ jednotlivca. V propagačnom videu sú tak na jednej úrovni "gény“ francúzske, britské, írske, španielske, talianske,... a východoeurópske. Aké osviežujúce bolo s kritikou tohto videa študentom ponúknut rozhovor Miloša Krekoviča s genetikom Mariánom Baldovičom. Rozhovor je výbornou demýtizáciou presvedčení, že by mohli geneticky jestvovat napríklad „starí Slováci“. V prvom rade, v celej Európe je viac potomkov paleolitických lovcov a zberačov, než neolitických rol'níkov. Podstatné však je, že „národy, národnosti či jazykové skupiny v genetike prakticky nejestvujú. (...) Aj keby jestvovali starí Slováci, geneticky by sme neboli ich väčší dedičia ako trebárs Mad’ari. Geografická blízkost’ bola pre náš genofond podstatnejšia ako etnografická, kultúrna, či jazyková blízkost' Slovákov k ostatným skupinám Slovanov“ (Krekovič, 2015).

Nie $v$ každej spoločnosti či geopolitickom priestore a nie $v$ každom čase sa ludia definovali a definujú cez rasu či etnicitu. $\vee$ minulosti bola dôležitejšia stavovská príslušnost’ a konfesionalita (Botík, 2021), dnes to môže byṫ získaná identita cez činnost' v nadnárodných korporáciách a v rôznych ideologicky zameraných zoskupeniach. Obrátme však svoju pozornost’ spät na spôsob získavania a interpretácie dát.

\section{Historické naratívy a „Pravda“ v oku pozorovatel’a}

„Aké Oko - taký Objekt“ („As the Eye - such the Object“) Týmto citátom Williama Blakea režisér Theo Anthony (USA) otvára film All light, everywhere (Všetko jasné!), ktorý sme mali možnost' vidiet $v$ rámci festivalu „Jeden svet“ 2021. Film je pre túto diskusiu podnetný v spôsobe, akým vedie dialóg s divákom: strieda opis zberu dôkazného materiálu pomocou používania telových kamier ( $v$ policajnom zbore USA) s históriou zachytávania obrazu ako takého, aj pre prípadnú identifikáciu nepriatel'ov.

Nedokonalosti ludského videnia provokovali k mnohým vynálezom. Autorovi sa darí ukázat', ako tesne idú ruka v ruke technológie produkcie obrazu a interpretácia nových „dôkazov“, aj ako blízko má k sebe kriminalistika, forenzná antropológia aj etnológia.

Vynálezca prvej fotopušky využil princíp gul'ometu a rozdelil predtým plynulo vnímaný 
pohyb na sekvencie s vlastnými súradnicami. Každý záber (shot) má vlastný rámec a kontext, ktorý už nezachytáva, no napriek tomu vzbudzuje dojem objektivity - trafil. Snímka nezobrazuje svet za svojimi hranicami, ale ak sa dobre pozeráme, táto hranica sa vždy objaví (pri skladaní snímok zhora sa občas stratí bodka - človek). Snímka je zásahom, a podobne ako balistické technológie, vie dosiahnut' d’aleko a sem-tam netrafí.

Záznam mechaniky pohybu ukazuje nové neviditel'né vzory sveta - prístrojmi, ktoré sú s udivujúcou presnostou predurčené „nahradit’ pozorovatel'a“. '́udské zmysly tvoria klamlivé zdania, preto polícia v USA používa telové kamery, ktorých audit môžu predložit’ na súde ako doklad o originalite dôkazu. Táto „pamätová pomôcka policajta“ mu umožňuje upravit’ vyhlásenie v súlade s dostupným videom. Nový naratív tak môže retroaktívne ospravedlnit’ použitie sily. Ostáva však otázka, ktorú si etnografia kladie často (Bužeková, Jerotijević, 2012): „Ked’ snímka rozpráva, o čom hovorí?“

Ked’ obrázky v učebniciach rozprávajú „samé za seba“, o čom hovoria? Do akého dialógu dostávajú vybrané obrázky učitel'stvo a žiactvo? Ako predíst' výlučnosti pohl'adu majority (okom štátu), a uniknút’ pasci monoperspektivity? Súčasná historiografia sa snaží aj o vtáčiu perspektívu (ako i policajný monitoring záberov z dronov, z verejných kamier či satelitov). Pre porozumenie pohybov a zmien $v$ historických naratívoch je posolstvo filmu trefné: „Akt sledovania je zásahom. Nevidíme svet, ale tento zásah“ (Anthony, 2020). Presne ako pointa Rogersa Brubakra: „Etnicita nie je vec o sebe, ale perspektíva na svet“ (Brubaker, 2006). V súvislosti s predošlou argumentáciou, problém nie je v jestvovaní stereotypu, ale v stotožnení sa s ním.

V roku 1879 Alphonse Bertillon predstavil systém sledovania podozrivých, kde osobu po zatknutí odfotia a odmerajú jej jedenást’ antropometrických mier. „Hovoriace portréty“ hovoria mierami, „preukázatel’ne“. Na ilustračných obrázkoch sú všetci oblečení v bielych košeliach a spolupracujú. Na kurzoch k štandardizácii týchto metód mal Bertillon obl'úbený citát: „Oko vidí v každej veci len to, čo v nej hl'adá, a hl'adá v nej len to, o čom už má predstavu“ (Anthony, 2020). Celkom v zhode s tým, čo vieme o povahe kognitívnych skreslení, aj o etnocentrizme.

Vo výskume je potrebné vyhnút’ sa práve tejto slepej škvrne a neaplikovat’ rámce vlastnej kultúry na hodnotenie inej kultúry. Etnocentrizmus býva spájaný s pojmami, ako kultúrna nadradenost', stereotypizácia, niekedy aj rasizmus, pričom sa odkazuje nielen na etnické, ale hlavne na kultúrne a sociálne identifikácie. Metodologický etnocentrizmus znamená, že autor nadrad'uje hlavnoprúdovú výskumnú metodológiu (alebo aj teóriu) na úkor iných, pričom býva jednou z foriem metodologického neokolonializmu. Jeho opakom je dekolonizácia, teda paritné zapojenie perspektív predstavitel’ov skúmanej skupiny (v zbere, v interpretácii dát, aj v sebaprezentácii).

Jeden z historicky známych príkladov etnocentrického postupu je v počiatkoch eugeniky. Tento pojem (= dobre narodený) ako prvý v r. 1879 použil Francis Galton, bratanec Charlesa Darwina. Ako prvý tiež predstavil techniku kompozitnej fotografie. Kolekciu obrázkov zoradil podl'a typov: kriminálnik, pacient s tuberkulózou, rodinná podobnost', americký vedec, židovský typ, pričom snímky naskladal na fotoplatňu a ukázal ich priemer a odchýlky. Galton tvrdil, že „všetko spoločné zostáva, a všetko individuálne má sklon zmiznút"“ (Anthony, 2020). 
Jeho obrazová štatistika zločincov mala predpovedat' (podobne ako predtým predpovedal počasie), ako vyzerá človek, ktorý má sklon upadnút do zločinu, no miesto toho nám zanechal vlastnú predstavu zločinca. Nikdy totiž nevysvetlil, na základe akých kritérií sa rozhodol, ktoré snímky zahrnie. $V$ tejto chvíli filmu vidíme prechody medzi snímkami zlievané tak, ako je to známe zo súčasných videoúprav kompozitných tvárí - vyzerajú presvedčivo, no v skutočnosti nejestvujú.

Galtonova Eugenika „je ako strom, ktorý čerpá materiály z mnohých zdrojov a organizuje ich do harmonickej entity“ (Anthony, 2020). Jeho stredovými koreňmi je genetika, antropológia, etnológia, geografia, štatistika a mnohé iné cez antropometriu, mentálne testovanie až po náboženstvo a politiku. Ešte pred pár rokmi by som toto považovala za svedectvo o prežitku. Stačí si však vypočut súčasné správy - temer neprejde deň, aby v nich nebola zmienka o činoch l'udí, s propagandistickými posolstvami „nového veku“ a s filozofiou tzv. čistých rás, kde je „všetko jasné“. Jasné ako cliché, fixované ako stereotyp. No ako povedal Bergson (1911: 302), skutočná je len neustála zmena formy.

\section{Referencie}

Anthony, T. (Režisér). (2021). All light, everywhere! [Všetko jasné!] [Film]. Super LTD.

Atran, S. (2010). Talking to the enemy: violent extremism, sacred values, and what it means to be human. London: Allen Lane.

Bergson, H. (1911). Creative Evolution. New York: Henry Holt and Company.

Botík, J. (2007). Etnická história Slovenska. Bratislava: Lúč.

Botík, J. (2021). Zástoj konfesionality v živote slovenských enkláv v stredovýchodnej Európe. Ethnologia Slovaca et Slavica, 43 (v tlači).

Botík, J., Hrušíková, E. a kol. (2020). Národnostné menšiny - zoznámme sa. Bratislava: Štátny pedagogický ústav Bratislava. https://www.statpedu.sk/files/sk/vyskum/ publikacna-cinnost/ucebne-texty/narodnostne-mensiny-zoznamme-sa.pdf

Brubaker, R. (2006). Ethnicity without Groups. Cambridge: Harvard University Press.

Bužeková, T. a Jerotijević, D. (Eds.). (2012). Metodologické problémy etnografického výskumu. Bratislava: Ústav enológie SAV.

Dass, A. (b. d.). Humanae. https://angelicadass.com/photography/humanae/

Eriksen, T. H. (1995). We and Us: Two Modes of Group Identification. Journal of Peace Research, 32(4), 427-436.

Eriksen, T. H. (2015). The Meaning of 'we'. In: P. A. Kraus, P. Kivisto (Eds.), The challenge of minority integration (s. 2-21). Berlin: De Gruyter Open.

Hrabovský, M. (2018). Rasa. Rasová klasifikácia l'udí. Bratislava: Veda.

Hugenberg, K., Miller, J. a Claypool, H. M. (2007). R). Categorization and individuation in the cross-race recognition deficit: Toward a solution to an insidious problem. Journal of Experimental Social Psychology, 43(2), 334-340.

Jablonski, N.G. (2012). The struggle to overcome racism. New Scientist, 9(1), 26-29. 
Kanovský, M. (2004). Etnická identita, kognitívny prístup a terénny výskum: Ako na to. Etnologické rozpravy, 11(2), 11-24.

Kottak, C. P. (1983). Assault on Paradise: Social Change in a Brazillian Village. New York: McGraw-Hill.

Krekovič, M. (18. 4. 2015). Genetik: Sme rovnako Mad’armi ako sú oni starými Slovákmi. Denník N. https://dennikn.sk/103926/genetik-sme-rovnako-madarmi-ako-su-oni-starymislovakmi/

Lešková, D. a Uhrin, M. (2020). Postoje majority na Slovensku k rómskej menšine. Etnologické rozpravy, 27(1), 71-92.

Sørensen, S. G. (10. 6. 2016). The DNA Journey: how it was made. Momondo. https://www.momondo.com/discover/momondo-the-dna-journey-how-it-was-made Tomek, I. (2018). Stereotyp. In Z. R. Nešpor (Ed.), Sociologická encyklopedie. Praha: Sociologický Ústav AV ČR. https://encyklopedie.soc.cas.cz/w/Stereotyp

Wikipedia (b. d.). Stereotype (printing). In Wikipedia. Získané 2. 12. 2021, z https://en.wikipedia.org/wiki/Stereotype_(printing) 